\title{
Metal carbonyl complexes of some aromatic ortho bis(methylthio)ethers
}

\author{
Michael E. Peach ${ }^{1}$ and Christian Burschka \\ Institut für Anorganische Chemie der Universität Würzburg, Am Hubland, 8700 Würzburg, West Germany \\ Received January 7, 1982
}

Michael E. Peach and Christian Burschka. Can. J. Chem. 60, 2029 (1982).

Various complexes of the type $\mathrm{M}(\mathrm{CO})_{4} \mathrm{~L}$ and $\left[\mathrm{M}(\mathrm{CO})_{4}\right]_{2} \mathrm{~L}, \mathrm{M}=\mathrm{Cr}, \mathrm{Mo}$, W, have been prepared and characterized. A series of aromatic ortho bis(methylthio)ethers were used as the ligand L. The crystal structures of the free ligand $\mathrm{C}_{6}\left(\mathrm{SCH}_{3}\right)_{6}$ and of the complex $\mathrm{Cr}(\mathrm{CO})_{4} \mathrm{C}_{6}\left(\mathrm{SCH}_{3}\right)_{6}$ are reported.

Michael. E. Peach et Christian Burschka. Can. J. Chem. 60, 2029 (1982).

On a préparé divers complexes du type $\mathrm{M}(\mathrm{CO})_{4} \mathrm{~L}$ et $\left[\mathrm{M}(\mathrm{CO})_{4}\right]_{2} \mathrm{~L}$, où $\mathrm{M}=\mathrm{Cr}, \mathrm{Mo}$, W, et on les a identifiés. On a utilisé une série d'ortho bis (méthylthio) éthers aromatiques comme ligand L. On rapporte la structure cristalline du ligand libre $\mathrm{C}_{6}\left(\mathrm{SCH}_{3}\right)_{6}$ et celle du complexe $\mathrm{Cr}(\mathrm{CO})_{4} \mathrm{C}_{6}\left(\mathrm{SCH}_{3}\right)_{6}$.

[Traduit par le journal]

The ligating properties of several chelating sulfur ligands, particularly with various metal carbonyls and the platinum group metals, are the subject of continuing study (1-13). It has been shown that aromatic ortho bisthioethers form complexes with a number of metal ions (1). All of the complexes with simple metal ions were polymeric and could not be purified by recrystallization.

Various chromium, molybdenum, and tungsten carbonyl complexes can be formed by potentially chelating sulfur ligands. The aliphatic bisthioethers, $\mathrm{RS}\left(\mathrm{CH}_{2}\right)_{x} \mathrm{SR}(\mathrm{L})$, give the complexes $\mathrm{M}(\mathrm{CO})_{5} \mathrm{~L},\left[\mathrm{M}(\mathrm{CO})_{5}\right]_{2} \mathrm{~L}$, and $\mathrm{M}(\mathrm{CO})_{4} \mathrm{~L}(2-6)$. However, the latter complex, $\mathrm{M}(\mathrm{CO})_{4} \mathrm{~L}$, is only obtained when $x=2$, and the complex contains a five-membered ring. Similar complexes have been prepared with some ortho bisthioethers (L1, L3, $\mathrm{L} 9, \mathrm{~L} 10)(1,7,8)$ and tetrakis(alkylthio)ethenes (9). The tetrakis(alkylthio)ethenes could form two fivemembered chelate rings in complexes such as $\left[\mathrm{M}(\mathrm{CO})_{4}\right]_{2} \mathrm{~L}$, although these were not reported (9). The crystal structure of $\mathrm{W}(\mathrm{CO})_{4} \mathrm{~L}, \mathrm{~L}=$ $o-(\mathrm{MeS}){ }_{2} \mathrm{C}_{6} \mathrm{H}_{4}$, has been noted (7).

Molybdenum and tungsten hexacarbonyls react with the macrocyclic ligand 2,6,15,19-tetrathia[7.7]paracyclophane (TTPH) to form the complexes TTPH $\left[\mathrm{M}(\mathrm{CO})_{4}\right]_{2} .2 \mathrm{C}_{6} \mathrm{H}_{6}(\mathrm{M}=\mathrm{Mo}, \mathrm{W})$ and TTPH $\left[\mathrm{W}(\mathrm{CO})_{5}\right]_{2}(10)$. The former two involve the coordination of the $\mathrm{M}(\mathrm{CO})_{4}$ unit to two sulfur atoms and the formation of a six-membered ring, basically $\mathrm{M}(\mathrm{CO})_{4} \mathrm{RS}\left(\mathrm{CH}_{2}\right)_{3} \mathrm{SR}^{\prime}$. However, with chromium hexacarbonyl several products are formed, the main one being the $\pi$ complex $\left(\eta^{6} \mathrm{TTPH}\right)$ chromium tricarbonyl (11). Other

${ }^{1}$ On leave from Acadia University, Wolfville, N.S., Canada B0P $1 X 0$ and to whom correspondence should be addressed at Acadia University. products characterized include elimination of the 1,3-propanedithia unit, and coordination of $\mathrm{Cr}(\mathrm{CO})_{4}$ or $\mathrm{Cr}(\mathrm{CO})_{5}$ units to sulfur atoms.

A further series of potential sulfur containing ligands of formula $\mathrm{C}_{6}(\mathrm{SMe})_{x} \mathrm{H}_{6-x}$ has been prepared (14). This paper is an extension of previous studies of the ligand properties of aromatic ortho bis(methylthio)ethers (1), with particular reference to the chromium, molybdenum, and tungsten carbonyl complexes. The ligands studied (L1, L2, L3, L4, L5, L6, L7, and L8) are shown below.
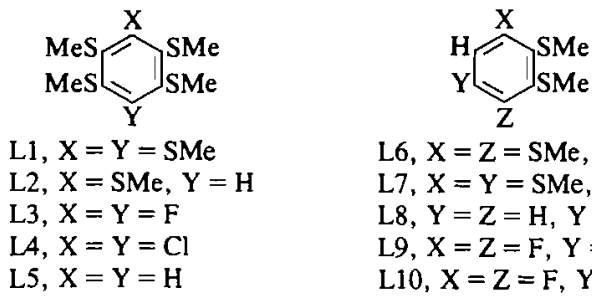

L6, $X=Z=S M e, Y=H$

L7, $X=Y=S M e, Z=H$

L8, $Y=Z=H, Y=S M e$

L9, $X=Z=F, Y=S M e$

L10, $X=Z=F, Y=H$

Various carbonyl complexes can be postulated, depending on the specific ligand. All the ligands should form the simple complexes $\mathrm{M}(\mathrm{CO})_{4} \mathrm{~L}(1)$,<smiles>C[As]1(C)Sc2ccccc2C1[N+](=O)[O-]</smiles>

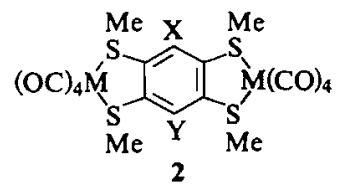

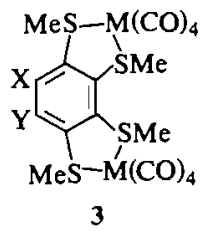

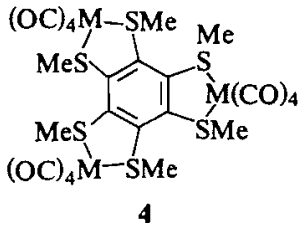

whereas the ligands L1, L2, L3, L4, L5, and L6 have two potentially chelating functions and the 
TABle 1. Products and analyses

\begin{tabular}{|c|c|c|c|c|c|c|c|c|c|c|c|}
\hline \multirow[b]{2}{*}{ Product } & \multirow[b]{2}{*}{ Color } & \multirow{2}{*}{$\begin{array}{l}\text { Decomp. } \\
\text { temp. } \\
\left({ }^{\circ} \mathrm{C}\right)\end{array}$} & \multirow[b]{2}{*}{ Method } & \multirow{2}{*}{$\begin{array}{l}\text { Ratio } \\
\text { M:L }\end{array}$} & \multirow[b]{2}{*}{ Solvent† } & \multirow[b]{2}{*}{ Time } & \multirow{2}{*}{$\begin{array}{l}\text { Yield } \neq \\
(\%)\end{array}$} & \multicolumn{2}{|c|}{ Found $(\%)$} & \multicolumn{2}{|c|}{ Calcd. $(\%)$} \\
\hline & & & & & & & & $\mathrm{C}$ & $\mathrm{H}$ & $\mathrm{C}$ & $\mathrm{H}$ \\
\hline $\mathrm{Cr}(\mathrm{CO})_{4} \mathrm{~L}$ & Yellow & 113 & A & $2: 1$ & tol & $20 d$ & 32 & 37.2 & 3.37 & 37.1 & 3.50 \\
\hline $\mathrm{Mo}(\mathrm{CO})_{4} \mathrm{~L}$ & Green-yellow & 95 & $A$ & $\begin{array}{l}1: 1 \\
2: 1\end{array}$ & $\begin{array}{l}\text { tol } \\
\text { hex }\end{array}$ & $\begin{array}{l}16 \mathrm{~h} \\
2 \mathrm{~d}\end{array}$ & $\begin{array}{l}77 \\
56\end{array}$ & 34.6 & 3.06 & 34.2 & 3.22 \\
\hline $\mathrm{W}(\mathrm{CO})_{4} \mathrm{~L} 1$ & Lemon & $110-111^{*}$ & $\begin{array}{l}\mathrm{B} \\
\mathrm{C} \\
\mathrm{C}\end{array}$ & $\begin{array}{l}1.2: 1 \\
1.2: 1 \\
1: 1\end{array}$ & $\begin{array}{c}\text { THF } \\
\text { THF } \\
\mathrm{CH}_{2} \mathrm{Cl}_{2}\end{array}$ & $\begin{array}{c}12 \mathrm{~m} \\
1.5 \mathrm{~h} \\
5 \mathrm{~h}\end{array}$ & $\begin{array}{r}4 \\
25 \\
11\end{array}$ & 30.2 & 3.00 & 29.5 & 2.79 \\
\hline$\left[\mathrm{Cr}(\mathrm{CO})_{4}\right]_{2} \mathrm{~L} 1$ & Orange & 170 & $\mathrm{D}$ & $2: 1$ & EtOH,P & $18 \mathrm{~h}$ & 62 & 33.6 & 2.92 & 35.2 & 2.64 \\
\hline$\left[\mathrm{Mo}(\mathrm{CO})_{4}\right]_{2} \mathrm{~L} 1$ & Yellow & 155 & A & $2: 1$ & tol & $2 d$ & 80 & 31.0 & 2.83 & 31.2 & 2.35 \\
\hline$\left[\mathrm{W}(\mathrm{CO})_{4}\right]_{2} \mathrm{~L} 1$ & Yellow-brown & 130 & C & $3: 1$ & THF & $2 \mathrm{~h}$ & 9 & 26.3 & 2.11 & 25.4 & 1.92 \\
\hline $\mathrm{Cr}(\mathrm{CO})_{4} \mathrm{~L} 2$ & Yellow & 135 & $\begin{array}{l}\text { A } \\
\text { B } \\
\text { D }\end{array}$ & $\begin{array}{l}1: 1 \\
2: 1 \\
2: 1\end{array}$ & $\begin{array}{c}\text { tol } \\
\text { THF } \\
\text { EtOH,P }\end{array}$ & $\begin{array}{c}6 \mathrm{~d} \\
45 \mathrm{~m} \\
21 \mathrm{~h}\end{array}$ & $\begin{array}{l}33 \\
54 \\
83\end{array}$ & 38.0 & 3.56 & 38.1 & 3.41 \\
\hline $\mathrm{Mo}(\mathrm{CO})_{4} \mathrm{~L} 2$ & Green-yellow & 125 & $\begin{array}{l}\mathrm{A} \\
\mathrm{A}\end{array}$ & $\begin{array}{l}2: 1 \\
2: 1\end{array}$ & $\begin{array}{c}\text { hex,P } \\
\text { tol,P }\end{array}$ & $\begin{array}{l}2 d \\
1 d\end{array}$ & $\begin{array}{l}31 \\
23\end{array}$ & 34.8 & 2.79 & 34.9 & 3.12 \\
\hline $\mathrm{W}(\mathrm{CO})_{4} \mathrm{~L} 2$ & Yellow-brown & 130 & $\mathrm{C}$ & $1: 1$ & THF & lh & 24 & 29.4 & 3.46 & 29.8 & 2.67 \\
\hline $\mathrm{Mo}(\mathrm{CO})_{4} \mathrm{~L} 3$ & Light brown & $66-68^{*}$ & A & $1: 1$ & tol & $1 \mathrm{~d}$ & 70 & 33.4 & 2.41 & 33.1 & 2.39 \\
\hline$\left[\mathrm{Cr}(\mathrm{CO})_{4}\right]_{2} \mathrm{~L} 3$ & Orange & 115 & $\mathrm{D}$ & $2: 1$ & $\mathrm{EtOH}$ & $2 \mathrm{~d}$ & 25 & 34.4 & 2.17 & 34.5 & 1.93 \\
\hline$\left[\mathrm{Mo}(\mathrm{CO})_{4}\right]_{2} \mathrm{~L} 3$ & Yellow-brown & 120 & $\mathrm{~A}$ & $4: 1$ & $\mathrm{CH}_{2} \mathrm{Cl}_{2}$ & $10 d$ & 77 & 30.1 & 1.94 & 30.3 & 1.69 \\
\hline $\mathrm{Cr}(\mathrm{CO})_{4} \mathrm{~L} 4$ & Yellow & 135 & A & $1: 1$ & tol & $5 d$ & 50 & 33.5 & 3.40 & 33.9 & 2.44 \\
\hline $\mathrm{Cr}(\mathrm{CO})_{4} \mathrm{LS}$ & Yellow & 145 & $\begin{array}{l}\text { A } \\
\text { D }\end{array}$ & $\begin{array}{l}2: 1 \\
2: 1\end{array}$ & $\begin{array}{c}\text { tol } \\
\text { EtOH,P }\end{array}$ & $\begin{array}{c}5 d \\
22 h\end{array}$ & $\begin{array}{l}38 \\
84\end{array}$ & 39.7 & 3.47 & 39.4 & 3.31 \\
\hline $\mathrm{Mo}(\mathrm{CO})_{4} \mathrm{~L} 5$ & Pale green & 70 & $\mathrm{~A}$ & $1: 1$ & tol, $\mathrm{P}$ & $2 d$ & 43 & 35.4 & 2.94 & 35.7 & 3.00 \\
\hline $\mathrm{W}(\mathrm{CO})_{4} \mathrm{~L} 5$ & Lemon & 135 & $\mathrm{C}$ & $1: 1$ & THF & $1 \mathrm{~h}$ & 10 & 30.4 & 3.19 & 30.1 & 2.53 \\
\hline $\mathrm{Cr}(\mathrm{CO})_{4} \mathrm{~L} 6$ & Yellow & 130 & $\begin{array}{l}A \\
D\end{array}$ & $\begin{array}{l}1: 1 \\
2: 1\end{array}$ & $\begin{array}{c}\text { tol } \\
\text { EtOH,P }\end{array}$ & $\begin{array}{l}4 d \\
1 d\end{array}$ & $\begin{array}{l}23 \\
30\end{array}$ & 39.6 & 3.38 & 39.4 & 3.31 \\
\hline $\mathrm{Mo}(\mathrm{CO})_{4} \mathrm{L6}$ & Yellow-brown & 125 & $\mathrm{~A}$ & $1: 1$ & tol & $5 \mathrm{~h}$ & 53 & 35.3 & 3.19 & 35.7 & 3.00 \\
\hline $\mathrm{W}(\mathrm{CO})_{4} \mathrm{~L} 6$ & Lemon & 130 & $\mathrm{C}$ & $1.2: 1$ & THF & $2 \mathrm{~h}$ & 37 & 30.3 & 2.80 & 30.1 & 2.53 \\
\hline $\mathrm{Cr}(\mathrm{CO})_{4} \mathrm{~L} 7$ & Orange & $122-124 *$ & A & $1: 1$ & tol & $2 d$ & 43 & 39.5 & 3.30 & 39.4 & 3.31 \\
\hline $\mathrm{Mo}(\mathrm{CO})_{4} \mathrm{~L} 7$ & Brown-yellow & 128 & A & $1: 1$ & tol & $20 \mathrm{~h}$ & 75 & 36.6 & 3.15 & 35.7 & 3.00 \\
\hline $\mathrm{W}(\mathrm{CO})_{4} \mathrm{~L} 7$ & Yellow & 120 & $\mathrm{C}$ & $1.2: 1$ & THF & $2 \mathrm{~h}$ & 49 & 30.7 & 2.61 & 30.1 & 2.53 \\
\hline $\mathrm{Cr}(\mathrm{CO})_{4} \mathrm{~L} 8$ & Orange-yellow & $75-77^{*}$ & A & $1: 1$ & tol & Sd & 55 & 41.0 & 3.30 & 41.0 & 3.18 \\
\hline
\end{tabular}

complexes $\left[\mathrm{M}(\mathrm{CO})_{4}\right]_{2} \mathrm{~L}$, structure 2 or 3 , can be postulated. Similarly, it might be possible to prepare the complexes $\left[\mathrm{M}(\mathrm{CO})_{4}\right]_{3} \mathrm{~L}(4)$ from $\mathrm{L} 1$.

The complexes $\mathrm{M}(\mathrm{CO})_{4} \mathrm{~L}$ were readily prepared. Several attempts, mostly unsuccessful, were made to prepare the complexes $\left[\mathrm{M}(\mathrm{CO})_{4}\right]_{2} \mathrm{~L}$ using an excess of the carbonyl reactant. Although analogous complexes with one polyfunctional sulfur ligand bonded to two metals are not known, some similar complexes with two metals and two ligands have been prepared, such as $\mathrm{Rh}_{2} \mathrm{Cl}_{2}(\mu-\mathrm{CO})$ $\left(\mathrm{PhSCH}_{2} \mathrm{SPh}\right)_{2}$ (13) and the group $\mathrm{V}$ ligand complexes, $(\mathrm{OC})_{4} \mathrm{M}\left(\mathrm{EMe}_{2}-\mathrm{EMe}_{2}\right)_{2} \mathrm{M}(\mathrm{CO})_{4}, \mathrm{M}=\mathrm{Cr}$, $\mathrm{W}, \mathrm{Mo} ; \mathrm{E}=\mathrm{P}$, As, with six-membered rings (15).

The complexes were obtained from cis metal tetracarbonyls, $\mathrm{M}(\mathrm{CO})_{4} \mathrm{X}_{2}$, specifically norbornadiene chromium and molybdenum tetracarbonyls and bis(acetonitrile)tungsten tetracarbonyl and the desired ligand in hexane, toluene, or THF solution (tungsten complexes). Some complexes were also prepared by irradiation of chromium hexacarbonyl to form $\mathrm{Cr}(\mathrm{CO})_{5}$. THF, which then reacted with the ligand or from $\mathrm{Et}_{4} \mathrm{~N}\left[\mathrm{Cr}(\mathrm{CO})_{5} \mathrm{Cl}\right]$ in ethanol. The yields were very low when tungsten hexacarbonyl was irradiated. The tungsten complexes could not be prepared from cis-bis(piperidine)molybdenum tetracarbonyl (16) as the free piperidine generated in the reaction reacted with the sulfur-containing ligand, presumably nucleophilically displacing a methylthio group.

The complexes isolated were mainly of the type $\mathrm{M}(\mathrm{CO})_{4} \mathrm{~L}$, see Table 1, and did not usually depend on the reactant stoichiometry. Although the chromium complex $\mathrm{Cr}(\mathrm{CO})_{4} \mathrm{~L}$ was readily prepared the complex $\left[\mathrm{Cr}(\mathrm{CO})_{4}\right]_{2} \mathrm{~L}$ was not obtained from an excess of $\mathrm{C}_{7} \mathrm{H}_{8} \mathrm{Cr}(\mathrm{CO})_{4}$ or $\mathrm{Cr}(\mathrm{CO})_{5} \mathrm{THF}$ with $\mathrm{L}$. The complexes $\left[\mathrm{Cr}(\mathrm{CO})_{4}\right]_{2} \mathrm{~L}(\mathrm{~L}=\mathrm{L} 1, \mathrm{~L} 3)$ were precipitated from ethanol solutions of $\mathrm{Et}_{4} \mathrm{~N}$ $\left[\mathrm{Cr}(\mathrm{CO})_{5} \mathrm{Cl}\right]$ and $\mathrm{L}$, in stoichiometry $2: 1$; under the same conditions with L2, L5, and L6 the complex $\mathrm{Cr}(\mathrm{CO})_{4} \mathrm{~L}$ precipitated. Even with reactant stoichiometry $3: 1 \mathrm{~W}(\mathrm{CO})_{4}(\mathrm{MeCN})_{2}: \mathrm{L}$ in THF solution 
it was generally only possible to isolate or detect in solution the complexes $\left[\mathrm{W}(\mathrm{CO})_{4} \mathrm{~L}\right]$. However, depending on the stoichiometry, the complexes $\mathrm{W}(\mathrm{CO})_{4} \mathrm{C}_{6}(\mathrm{SMe})_{6}$ and $\left[\mathrm{W}(\mathrm{CO})_{4}\right]_{2} \mathrm{C}_{6}(\mathrm{SMe})_{6}$ could be prepared. The reactions of $\mathrm{C}_{7} \mathrm{H}_{8} \mathrm{Mo}(\mathrm{CO})_{4}$ with the various ligands were usually studied in toluene solution where precipitation of $\operatorname{Mo}(\mathrm{CO})_{4} \mathrm{~L}$ sometimes occurred. The reactions with molar ratios $\mathrm{C}_{7} \mathrm{H}_{8} \mathrm{Mo}(\mathrm{CO})_{4}: \mathrm{L}, 2: 1$, were studied in either toluene or methylene chloride, depending on the solubility of $\mathrm{Mo}(\mathrm{CO})_{4} \mathrm{~L}$. The nmr spectra of the initial products indicated that although small amounts of $\left[\mathrm{Mo}(\mathrm{CO})_{4}\right]_{2} \mathrm{~L}$ may have been formed in several reactions, it was only possible to isolate this product when $\mathrm{L}=\mathrm{L} 1$ or $\mathrm{L} 3$. The molybdenum complexes were often formed with incorporation of some solvent in the crystal lattice. This was detected in the nmr spectra and thermal analysis showed a loss of weight (less than 5\%) accompanied by an endothermic change before decomposition. Incorporation of solvent benzene in some molybdenum complexes $\mathrm{Mo}(\mathrm{CO})_{4} \mathrm{~L}$ with sulfurcontaining ligands has been noted previously (10).

The formation of the complexes $\mathrm{Cr}(\mathrm{CO})_{4} \mathrm{~L}$ clearly depends on the bulk of the methyl group. When $p-\mathrm{F}_{2} \mathrm{C}_{6}\left(\mathrm{SBu}^{t}\right)_{4}$ was used as a potential ligand no reaction occurred in four days at $45^{\circ} \mathrm{C}$ with $\mathrm{C}_{7} \mathrm{H}_{8} \mathrm{Cr}(\mathrm{CO})_{4}$, although $\mathrm{C}_{7} \mathrm{H}_{8} \mathrm{Cr}(\mathrm{CO})_{4}$ reacted within 2 days with other ligands containing the methyl group at $45^{\circ} \mathrm{C}$. It can be inferred that the large tertiary butyl group blocks the coordination of the metal to the sulfur.

The number of ortho methylthio groups in a ligand also determines the ease of the reaction. In a reaction of $1 \mathrm{mmol}$ of $\mathrm{C}_{7} \mathrm{H}_{8} \mathrm{Cr}(\mathrm{CO})_{4}$ with $1 \mathrm{mmol}$ of each of $\mathrm{L} 1$ and $\mathrm{L} 5$ in toluene at $45^{\circ} \mathrm{C}$, the $\mathrm{C}_{7} \mathrm{H}_{8} \mathrm{Cr}(\mathrm{CO})_{4}$ had all reacted within one day. The nmr spectrum of the product, after removal of the solvent, showed that approximately $75 \%$ of $\mathrm{L} 1 \mathrm{had}$ formed the complex $\mathrm{Cr}(\mathrm{CO})_{4} \mathrm{~L} 1$. The ligand $\mathrm{L} 1$ with six possible ortho bis(methylthio) sites for coordination clearly forms the complex $\mathrm{Cr}(\mathrm{CO})_{4} \mathrm{~L}$ more readily than L5 which has only two ortho bis(methylthio) sites.

The structures of the products in solution were determined from their infrared and nmr (H-1) spectra. The spectroscopic data cannot, however, distinguish between the simple monomeric complex, $\mathrm{M}(\mathrm{CO})_{4} \mathrm{~L}$, and a dimer, such as $\mathbf{5}$. However, as the solutions used in the preparations were relatively concentrated $(0.05 M \sim 0.02 M)$, the possibility of the formation of 5 can be excluded. The crystal structure of $\mathrm{Cr}(\mathrm{CO})_{4} \mathrm{Ll}$ shows that it is monomeric in the solid state.

The carbonyl vibrations, tabulated in Table 2,

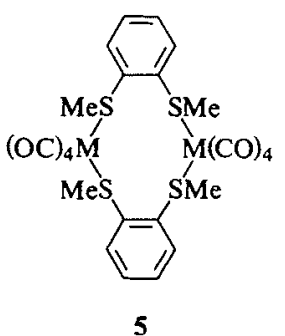

are all consistent with the established values for cis-tetracarbonyl complexes, cis- $\mathrm{M}(\mathrm{CO})_{4} \mathrm{X}_{2}(1,9)$. The proton nmr spectra were normally recorded in benzene or methylene chloride solutions (see Table 2). The complexes decomposed readily in solvents such as deuterochloroform in which they are readily soluble. The structure 1 is clearly indicated for the complexes $\mathrm{M}(\mathrm{CO})_{4} \mathrm{~L} 1$ as three distinct methyl groups are observed in the proton nmr spectra with intensity ratio $1: 1: 1$. Similarly, with the ligands L3, L4, L5, L7, and L8 where only one isomeric product is possible, the structure 1 is clearly indicated by the nmr spectra. The possibility of a $\pi$ complex, as occurs in bis(methylthio- $\eta$ benzene) chromium (18) and the $\eta^{6}$ arene compound $\mathrm{Cr}(\mathrm{CO})_{3} \mathrm{C}_{6} \mathrm{H}_{5}-\mathrm{SC}_{6} \mathrm{H}_{5}(19)$ can be excluded.

Comparison of the $\mathrm{nmr}$ spectra of the complexes and the free ligand in $\mathrm{CH}_{2} \mathrm{Cl}_{2}$ or $\mathrm{CDCl}_{3}$ solution shows that the protons of the methyl group bonded to the ligand sulfur in the complexes $\mathrm{M}(\mathrm{CO})_{4} \mathrm{~L}$ are deshielded by approximately $0.30 \mathrm{ppm}(\mathrm{Cr})$, $0.38 \mathrm{ppm}(\mathrm{Mo})$, and $0.57 \mathrm{ppm}(\mathrm{W})$ and that there is somewhat greater deshielding in the complexes $\left[\mathrm{M}(\mathrm{CO})_{4}\right]_{2} \mathrm{~L}$. Similar deshielding has been observed in the complexes $\mathrm{M}(\mathrm{CO})_{5} \mathrm{SRR}^{1}(\mathrm{M}=\mathrm{Cr}$, Mo, W), with the magnitude of the deshielding $\mathrm{Cr}<$ Mo $<W(19,20)$. The chemical shifts of the other methyl protons are relatively unchanged in comparison with the free ligand. This deshielding effect is not as clearly observed in benzene solution, with respect to the free ligand, but the magnitude of the deshielding is still $\mathrm{Cr}<\mathrm{Mo}<\mathrm{W}$.

With the ligands L2 and L6, two isomeric products $\mathrm{M}(\mathrm{CO})_{4} \mathrm{~L}$ can be postulated, 6 and 7 .

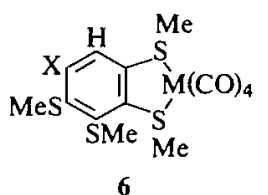

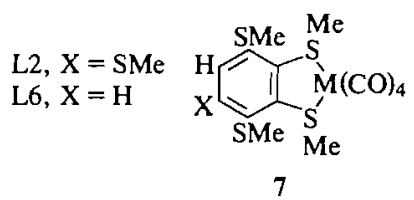

7
The $n m r$ spectra of both the $\mathrm{M}(\mathrm{CO}){ }_{4} \mathrm{~L}(\mathrm{~L}=\mathrm{L} 2, \mathrm{~L} 6)$ complexes indicate that only one isomeric product is formed. The structure 7 is clearly shown in the spectrum of the L6 complexes as only two methyl proton signals are observed. Similarly, it can be postulated from the observed spectrum of L2 and 
TABLE 2. CO absorptions and summary of nmr data

\begin{tabular}{|c|c|c|}
\hline Compound & CO absorptions $\left(\mathrm{cm}^{-1}\right)^{*}$ & $\mathrm{H}$ nmr chemical shifts (ppm) and intensity ratios $\dagger$ \\
\hline $\begin{array}{l}\quad \mathrm{L} 1 \\
\mathrm{Cr}(\mathrm{CO})_{4} \mathrm{Ll} \\
\mathrm{Mo}(\mathrm{CO})_{4} \mathrm{Ll} \\
\mathrm{W}(\mathrm{CO})_{4} \mathrm{~L} 1 \\
{\left[\mathrm{Cr}(\mathrm{CO})_{4}\right]_{2} \mathrm{Ll}} \\
{\left[\mathrm{Mo}(\mathrm{CO})_{4}\right]_{2} \mathrm{Ll}} \\
{\left[\mathrm{W}(\mathrm{CO})_{4}\right]_{2} \mathrm{Ll}}\end{array}$ & $\begin{array}{l}2014 \mathrm{~s}, 1912 \mathrm{sh}, 1902 \mathrm{vs}, 1881 \mathrm{~s} \\
2021 \mathrm{~s}, 1915 \mathrm{sh}, 1910 \mathrm{vs}, 1886 \mathrm{~s} \\
2018 \mathrm{~s}, 1905 \mathrm{sh}, 1901 \mathrm{vs}, 1882\left(\mathrm{C}_{6} \mathrm{H}_{6}\right) \\
2015 \mathrm{~s}, 1915 \mathrm{sh}, 1908 \mathrm{vs}, 1878\left(\mathrm{CH}_{2} \mathrm{Cl}_{2}\right) \\
2024 \mathrm{~s}, 1923 \mathrm{vs}, 1920 \mathrm{~s}, 1881 \mathrm{~s}\left(\mathrm{CH}_{2} \mathrm{Cl}_{2}\right) \\
2016 \mathrm{~s}, 1912 \mathrm{sh}, 1905 \mathrm{vs}, 1883 \mathrm{~s}(\mathrm{THF})\end{array}$ & $\begin{array}{l}2.49 \mathrm{~s} \\
2.76 \mathrm{~s}, 2.54 \mathrm{~s}, 2.52 \mathrm{~s}(1: 1: 1) \\
2.83 \mathrm{~s}, 2.53 \mathrm{~s}, 2.51 \mathrm{~s}(1: 1: 1) \\
2.99 \mathrm{~s}, 2.55 \mathrm{~s}, 2.54 \mathrm{~s}(1: 1: 1) \\
2.90 \mathrm{~s}, 2.65 \mathrm{~s}(2: 1) \\
2.92 \mathrm{~s}, 2.61 \mathrm{~s}(2: 1) \\
3.16 \mathrm{~s}, 2.65 \mathrm{~s}(2: 1)\end{array}$ \\
\hline $\begin{array}{l}\mathrm{L} 2 \\
\mathrm{Cr}(\mathrm{CO})_{4} \mathrm{~L} 2 \\
\mathrm{Mo}(\mathrm{CO})_{4} \mathrm{~L} 2 \\
\mathrm{~W}(\mathrm{CO})_{4} \mathrm{~L} 2\end{array}$ & $\begin{array}{l}2015 \mathrm{~s}, 1915 \mathrm{sh}, 1902 \mathrm{vs}, 1880 \mathrm{~s} \\
2022 \mathrm{~s}, 1914 \mathrm{sh}, 1911 \mathrm{vs}, 1884 \mathrm{~s} \\
2018 \mathrm{~s}, 1910 \mathrm{sh}, 1901 \mathrm{vs}, 1877 \mathrm{~s}\left(\mathrm{C}_{6} \mathrm{H}_{6}\right)\end{array}$ & $\begin{array}{l}2.49 \mathrm{~s}, 2.45 \mathrm{~s}, 2.37 \mathrm{~s}, 6.41 \mathrm{~s}(3: 6: 6: 1) \\
2.79 \mathrm{~s}, 2.64 \mathrm{~s}, 2.57 \mathrm{~s}, 2.49 \mathrm{~s}, 2.40 \mathrm{~s}, 6.90 \mathrm{~s}(3: 3: 3: 3: 3: 1) \\
2.85 \mathrm{~s}, 2.74 \mathrm{~s}, 2.57 \mathrm{~s}, 2.48 \mathrm{~s}, 2.40 \mathrm{~s}, 6.91 \mathrm{~s}(3: 3: 3: 3: 3: 1) \\
3.01 \mathrm{~s}, 2.90 \mathrm{~s}, 2.55 \mathrm{~s}, 2.46 \mathrm{~s}, 2.37 \mathrm{~s}, 6.84 \mathrm{~s}(3: 3: 3: 3: 3: 1)\end{array}$ \\
\hline $\begin{array}{l}\quad \mathrm{L3} \\
\mathrm{Cr}(\mathrm{CO})_{4} \mathrm{~L} 3 \\
\mathrm{Mo}(\mathrm{CO})_{4} \mathrm{~L} 3 \\
\mathrm{~W}(\mathrm{CO})_{4} \mathrm{L3} \\
{\left[\mathrm{Cr}(\mathrm{CO})_{4}\right]_{2} \mathrm{~L} 3} \\
{\left[\mathrm{Mo}(\mathrm{CO})_{4}\right]_{2} \mathrm{~L} 3}\end{array}$ & $\begin{array}{l}2020 \mathrm{~s}, 1925 \mathrm{~s}, 1910 \mathrm{~s}, 1890 \mathrm{~s}(\text { ref. } 1) \\
2028 \mathrm{~s}, 1920 \mathrm{sh}, 1916 \mathrm{vs}, 1891 \mathrm{~s} \\
2018 \mathrm{~s}, 1925 \mathrm{~m}, 1907 \mathrm{~m}, 1901 \mathrm{~m}(\text { ref. } 1) \\
2022 \mathrm{~s}, 1922 \mathrm{sh}, 1918 \mathrm{vs}, 1886 \mathrm{~s}\left(\mathrm{CH}_{2} \mathrm{Cl}_{2}\right) \\
2026 \mathrm{~s}, 1926 \mathrm{vs}, 1920 \mathrm{sh}, 1887 \mathrm{~s}\left(\mathrm{CH}_{2} \mathrm{Cl}_{2}\right)\end{array}$ & $\begin{array}{l}2.45 \mathrm{~T}(J(\mathrm{H}-\mathrm{F}) 1.0 \mathrm{~Hz}) \ddagger \\
2.77 \mathrm{~s}, 2.59 \mathrm{~T}(J(\mathrm{H}-\mathrm{F}) 0.55 \mathrm{~Hz})(\text { ref. } 1)(1: 1) \\
2.81 \mathrm{~s}, 2.55 \mathrm{~T}(J(\mathrm{H}-\mathrm{F}) 1.1 \mathrm{~Hz})(1: 1) \ddagger \\
2.98 \mathrm{~s}, 2.54 \mathrm{~T}(J(\mathrm{H}-\mathrm{F}) 1.3 \mathrm{~Hz})(\text { ref. } 1)(1: 1) \\
2.81 \mathrm{~s} \\
2.87 \mathrm{~s}\end{array}$ \\
\hline $\begin{array}{c}\mathrm{L} 4 \\
\mathrm{Cr}(\mathrm{CO})_{4} \mathrm{~L} 4\end{array}$ & $2018 \mathrm{~s}, 1920 \mathrm{sh}, 1902 \mathrm{vs}, 1888 \mathrm{~s}$ & $\begin{array}{l}2.47 \mathrm{~s} \\
2.74 \mathrm{~s}, 2.50 \mathrm{~s}(1: 1)\end{array}$ \\
\hline $\begin{array}{l}\quad \mathrm{L5} \\
\mathrm{Cr}(\mathrm{CO})_{4} \mathrm{~L} 5 \\
\mathrm{Mo}(\mathrm{CO})_{4} \mathrm{~L} 5 \\
\mathrm{~W}(\mathrm{CO})_{4} \mathrm{~L} 5\end{array}$ & $\begin{array}{l}2016 \mathrm{~s}, 1915 \mathrm{sh}, 1903 \mathrm{vs}, 1879 \mathrm{~s} \\
2024 \mathrm{~s}, 1916 \mathrm{sh}, 1913 \mathrm{vs}, 1884 \mathrm{~s} \\
2018 \mathrm{~s}, 1903 \mathrm{sh}, 1899 \mathrm{vs}, 1876 \mathrm{~s} \text { (THF) }\end{array}$ & $\begin{array}{l}2.46 \mathrm{~s}, 7.05 \mathrm{~s}(6: 1) \\
2.72 \mathrm{~s}, 2.54 \mathrm{~s}, 7.42 \mathrm{~s}(3: 3: 1) \\
2.77 \mathrm{~s}, 2.51 \mathrm{~s}, 7.42 \mathrm{~s}(3: 3: 1) \\
2.94 \mathrm{~s}, 2.52 \mathrm{~s}, 7.45 \mathrm{~s}(3: 3: 1)\end{array}$ \\
\hline $\begin{array}{l}\quad \mathrm{L} 6 \\
\mathrm{Cr}(\mathrm{CO})_{4} \mathrm{~L} 6 \\
\mathrm{Mo}(\mathrm{CO})_{4} \mathrm{~L} 6 \\
\mathrm{~W}(\mathrm{CO})_{4} \mathrm{~L} 6\end{array}$ & $\begin{array}{l}2012 \mathrm{~s}, 1913 \mathrm{sh}, 1904 \mathrm{vs}, 1880 \mathrm{~s} \\
2022 \mathrm{~s}, 1915 \mathrm{sh}, 1911 \mathrm{vs}, 1883 \mathrm{~s} \\
2017 \mathrm{~s}, 1908 \mathrm{sh}, 1901 \mathrm{vs}, 1879 \mathrm{~s}\left(\mathrm{C}_{6} \mathrm{H}_{6}\right)\end{array}$ & $\begin{array}{l}2.39 \mathrm{~s}, 7.05 \mathrm{~s}(6: 1) \\
2.71 \mathrm{~s}, 2.55 \mathrm{~s}, 7.25 \mathrm{~s}(3: 3: 1) \\
2.75 \mathrm{~s}, 2.51 \mathrm{~s}, 7.23 \mathrm{~s}(3: 3: 1) \\
2.95 \mathrm{~s}, 2.54 \mathrm{~s}, 7.27 \mathrm{~s}(3: 3: 1)\end{array}$ \\
\hline $\begin{array}{l}\mathrm{L} 77 \\
\mathrm{Cr}(\mathrm{CO})_{4} \mathrm{~L} 7 \\
\mathrm{Mo}(\mathrm{CO})_{4} \mathrm{~L} 7 \\
\mathrm{~W}(\mathrm{CO})_{4} \mathrm{~L} 7\end{array}$ & $\begin{array}{l}2017 \mathrm{~s}, 1907 \mathrm{sh}, 1904 \mathrm{vs}, 1879 \mathrm{~s} \\
2024 \mathrm{~s}, 1920 \mathrm{sh}, 1910 \mathrm{vs}, 1883 \mathrm{~s} \\
2019 \mathrm{~s}, 1908 \mathrm{sh}, 1901 \mathrm{vs}, 1874 \mathrm{~s}\end{array}$ & $\begin{array}{l}2.47 \mathrm{~s}, 2.39 \mathrm{~s}, 2.24 \mathrm{~s}, 6.67 \mathrm{~s}(3: 6: 3: 2) \\
2.72 \mathrm{~s}, 2.60 \mathrm{~s}, 2.25 \mathrm{~s}, 7.25 \mathrm{~d}, 6.95 \mathrm{~d}(3: 3: 6: 1: 1) \S \\
2.83 \mathrm{~s}, 2.70 \mathrm{~s}, 2.55 \mathrm{~s}, 7.26 \mathrm{~d}, 6.94 \mathrm{~d}(3: 3: 6: 1: 1) \S \\
2.97 \mathrm{~s}, 2.86 \mathrm{~s}, 2.54 \mathrm{~s}, 7.28 \mathrm{~d}, 6.96 \mathrm{~d}(3: 3: 6: 1: 1) \S\end{array}$ \\
\hline $\begin{array}{c}\mathrm{L} 8 \\
\mathrm{Cr}(\mathrm{CO})_{4} \mathrm{~L} 8\end{array}$ & 2016s, 1920sh, 1902vs, 1888s & $\begin{array}{l}2.44 \mathrm{~s}, 2.42 \mathrm{~s}, 2.39 \mathrm{~s}, 7.06 \mathrm{~m}(1: 1: 1: 1) \\
2.72 \mathrm{~s}, 2.67 \mathrm{~s}, 2.50 \mathrm{~s}, 7.50 \mathrm{~m}(1: 1: 1: 1)\end{array}$ \\
\hline
\end{tabular}

the magnitude of the deshielding found in the other complexes that the probable structure of the $\mathrm{M}(\mathrm{CO})_{4} \mathrm{~L} 2$ complexes is also 7 , rather than 6 .

In the free ligand L3, the methyl protons are coupled to the fluorine, and appear as a triplet (17). This can be attributed to steric through space coupling, with free rotation about both the aromatic carbon-sulfur and the methyl carbon-sulfur bonds. In the complexes there is increasing rigidity of the aromatic carbon-sulfur bond, so that no coupling to fluorine is observed in $\left[\mathrm{M}(\mathrm{CO})_{4}\right]_{2} \mathrm{~L} 3$. However, in the complexes $\mathrm{M}(\mathrm{CO})_{4} \mathrm{~L} 3$, two distinct methyl groups are observed. The methyl group bonded to the coordinated sulfur is a singlet, whereas the methyl group bonded to noncoordinated sulfur still appears as a triplet.

While the structures of the complexes $\left[\mathrm{M}(\mathrm{CO})_{4}\right]_{2} \mathrm{~L} 3$ must be unambiguously assigned as
2 , it is not clear from the nmr spectra whether the complexes $\left[\mathrm{M}(\mathrm{CO})_{4}\right]_{2} \mathrm{~L} 1$ have structure 2 or 3 . Two distinct methyl groups are observed in the proton nmr spectrum, with intensity ratio 2:1.

Similarly, any complexes of the type $\left[\mathrm{M}(\mathrm{CO})_{4}\right]_{2} \mathrm{~L}$ could have structure 2 , when $\mathrm{L}=\mathrm{L} 2, \mathrm{~L} 5$, and structure 3, when $\mathrm{L}=\mathrm{L} 2$ or L6. There was no indication of any complexes $\left[\mathrm{M}(\mathrm{CO})_{4}\right]_{2} \mathrm{~L}$ being formed with L2, L5, or L6. If the complexes were formed with $\mathrm{L} 6$, some rearrangement must have occurred in the solution as the complexes $\mathrm{M}(\mathrm{CO})_{4} \mathrm{~L} 6$ all have structure 7 . The different abilities of the somewhat analogous ligands L 3 and $\mathrm{L} 5$ to form the $\left[\mathrm{M}(\mathrm{CO})_{4}\right]_{2} \mathrm{~L}$ complexes may be due to the differences in size of hydrogen and fluorine.

The crystal structures of the free ligand $\mathrm{C}_{6}\left(\mathrm{SCH}_{3}\right)_{6}, \mathrm{~L} 1$, and the chromium complex $\mathrm{Cr}(\mathrm{CO})_{4} \mathrm{~L} 1$ have been examined and compared. 
They are shown in Figs. 1, 2, and 3 and some bond lengths and angles are tabulated in Tables 3 and 4.

In the crystal all $\mathrm{C}_{6}\left(\mathrm{SCH}_{3}\right)_{6}$ molecules are found to have a crystallographic centre of symmetry in their middle. The $\mathrm{C}_{6} \mathrm{~S}_{6}$ fragment is only roughly planar. With the carbon atoms deviating from a best plane through the origin by $\pm 0.03 \AA$ (signs alternating) the benzene ring is slightly puckered. Deviations of the sulfur atoms from this plane are considerably higher (S1: $0.22 \AA, S 2: 0.25 \AA$; S3: $0.24 \AA$ ), probably caused by short non-bonding S...S-contacts (Table 3).

While the low temperature nmr spectrum of $\mathrm{C}_{6}\left(\mathrm{SCH}_{3}\right)_{6}\left(-75^{\circ} \mathrm{C}\right.$ in $\left.\mathrm{CS}_{2}\right)$ indicates that all the methyl groups are equivalent, in the solid state three adjacent methyl groups are situated above the plane, the other three below. The aromatic $\mathrm{C}-\mathrm{S}$ bond length and $\mathrm{S}-\mathrm{CH}_{3}$ bond lengths are as expected, but the aromatic $\mathrm{C}-\mathrm{S}$ bond length, average $1.78 \AA$, is approximately $0.05 \AA$ lower than the anticipated sum of the covalent radii (21); however, values of 1.74 and $1.76 \AA$ are reported in di- $p$-toly sulfide (22).

The structure of $\mathrm{Cr}(\mathrm{CO})_{4} \mathrm{C}_{6}\left(\mathrm{SCH}_{3}\right)_{6}$ does not show fundamental changes within the ligand. Still some changes in the SCCS torsion angles can be observed, possibly due to complexation, though it cannot be excluded that intermolecular packing gives rise to similar effects. Bonding to the chromium atom apparently reduces the angle S1C1C2S2 from the range of $11.7^{\circ}-13.6^{\circ}$ in the free ligand to $5.4^{\circ}$ in the complex, thus enabling the chelate ring to be more planar. Contrary to that, the carbon-sulfur bonds to S4 and S5 opposite the bonded part of the ligand enclose a torsion angle of $19.8^{\circ}$ which is unusual for adjacent $s p^{2}$-centres normally being

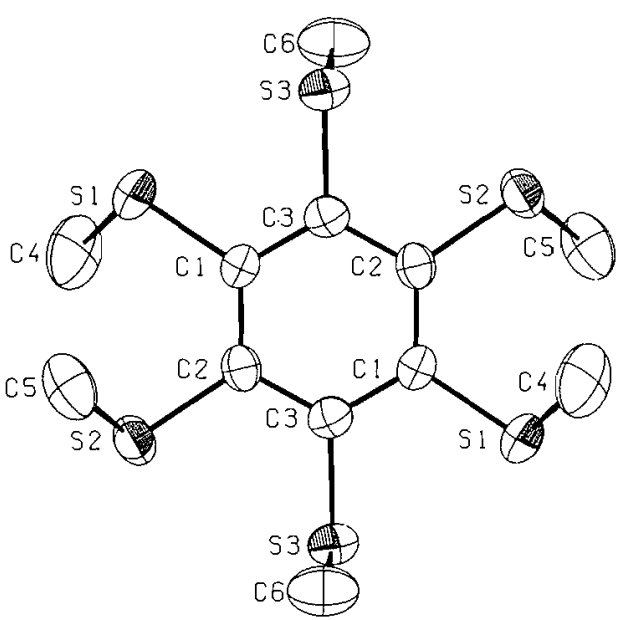

FIG. 1. ORTEP-plot ( $50 \%$ probability) of the molecule $\mathrm{C}_{6}\left(\mathrm{SCH}_{3}\right)_{6}$ direction of view perpendicular to the $C_{6}$-plane.

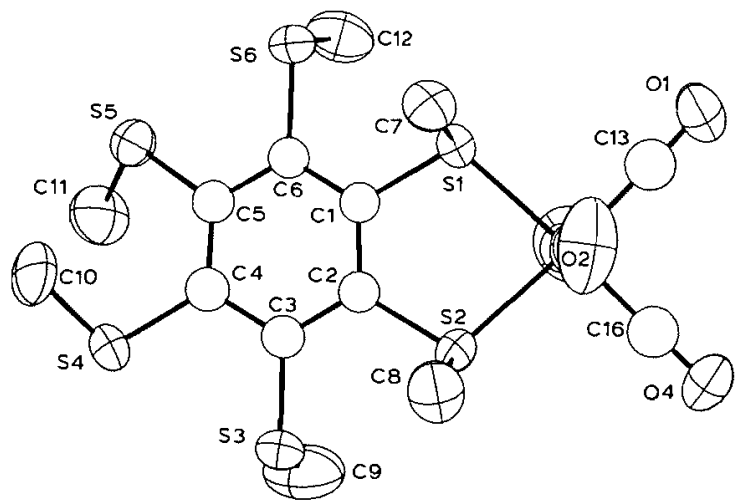

FIG. 2. ORTEP-plot (50\% probability) of the complex $\mathrm{Cr}(\mathrm{CO})_{4} \mathrm{~L} 1$ showing the atomic numbering scheme. Direction of view perpendicular to the plane $\mathrm{CrS} 1 \mathrm{~S} 2$ ( $\mathrm{C} 14$ and $\mathrm{C} 15$ axial: $\mathrm{C} 14$ above, $\mathrm{C} 14$ and $\mathrm{O} 3$ below the projection plane).

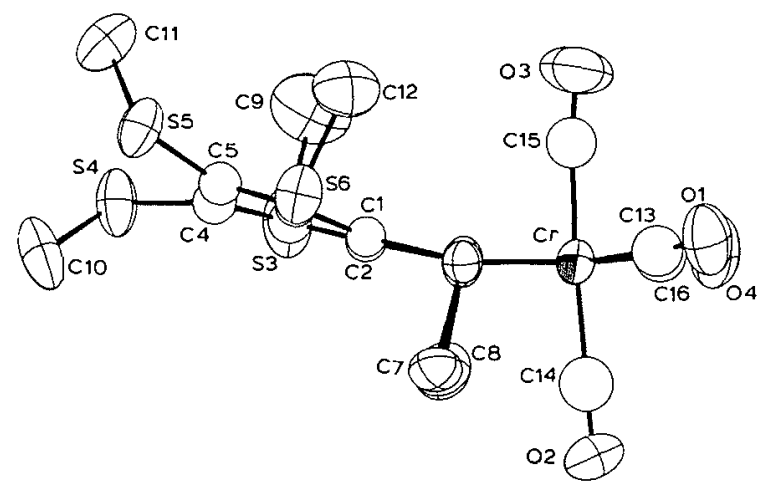

FIG. 3. OR TEP-plot (50\% probability) of the complex $\mathrm{Cr}(\mathrm{CO})_{4} \mathrm{~L} 1$ direction of view from atom $\mathrm{S} 1$ to atom $\mathrm{S} 2$.

coplanar. As for the aromatic carbon-bridging sulfur bond lengths, however, there is virtually no change from those observed in the free ligand.

In the crystal three of the methyl groups bonded to non-coordinated sulfur are on one side of the ligand plane and only one on the other. This may be due to packing as the room temperature $\mathrm{nmr}$ spectrum $\left(\mathrm{CH}_{2} \mathrm{Cl}_{2}\right)$ shows that there are three distinct methyl groups of equal intensity. On cooling the peaks broaden somewhat and below $-25^{\circ} \mathrm{C}$ the peaks due to the methyl attached to noncoordinated sulfur coalesce and a single broad peak is observed.

The methyl groups bonded to the coordinated sulfur are on the same side of the ligand plane. This was also observed in $\mathrm{W}(\mathrm{CO})_{4} \mathrm{~L}$ where $\mathrm{L}=$ $o$-(MeS) ${ }_{2} \mathrm{C}_{6} \mathrm{H}_{4}(7)$ and in the complex $\mathrm{Cr}(\mathrm{CO})_{4} \mathrm{~L}$, where $\mathrm{L}$ is tetrakis(methylthio)ethene (9). However, in the complexes $\mathrm{Cr}(\mathrm{CO})_{4} \mathrm{~L}$ where $\mathrm{L}$ is $\mathrm{RS}\left(\mathrm{CH}_{2}\right)_{n} \mathrm{SR}(n=2,3)$ and the bridging $\left(\mathrm{CH}_{2}\right)_{n}$ unit is saturated the groups $\mathrm{R}$ are anti $(5,6)$. 
TABLE 3. Some bond lengths and angles in $\mathrm{C}_{6}(\mathrm{SMe})_{6}$

\begin{tabular}{|c|c|c|c|}
\hline Bond & Length $(\AA)$ & Bond' & Angle (deg) \\
\hline $\mathrm{S} 1-\mathrm{C} 1$ & $1.778(2)$ & $\mathrm{C} 1-\mathrm{S} 1-\mathrm{C} 4$ & $103.8(2)$ \\
\hline $\mathrm{S} 1-\mathrm{C} 4$ & $1.805(4)$ & $\mathrm{C} 2-\mathrm{S} 2-\mathrm{C} 5$ & $102.4(1)$ \\
\hline $\mathrm{S} 2-\mathrm{C} 2$ & $1.778(2)$ & $\mathrm{C} 3-\mathrm{S} 3-\mathrm{C} 6$ & $101.8(1)$ \\
\hline $\mathrm{S} 2-\mathrm{C} 5$ & $1.795(3)$ & $\mathrm{C} 1-\mathrm{C} 2-\mathrm{S} 2$ & $123.5(2)$ \\
\hline $\mathrm{S} 3-\mathrm{C} 3$ & $1.779(2)$ & $\mathrm{C} 3-\mathrm{C} 2-\mathrm{S} 2$ & $117.2(2)$ \\
\hline S3-C6 & $1.794(4)$ & $\mathrm{C} 2-\mathrm{C} 1-\mathrm{S} 1$ & $124.3(2)$ \\
\hline $\mathrm{C} 1-\mathrm{C} 2$ & $1.402(3)$ & $\mathrm{C} 3-\mathrm{C} 1-\mathrm{S} 1$ & $116.4(2)$ \\
\hline $\mathrm{Cl}-\mathrm{C} 3$ & $1.403(3)$ & $\mathrm{Cl}-\mathrm{C} 3-\mathrm{S} 3$ & $119.4(2)$ \\
\hline $\mathrm{C} 2-\mathrm{C} 3$ & $1.405(3)$ & $\mathrm{C} 2-\mathrm{C} 3-\mathrm{S} 3$ & $119.7(2)$ \\
\hline \multicolumn{2}{|c|}{$\begin{array}{l}\text { Non-bonding } \\
\text { S...S-contacts }\end{array}$} & Atoms & $\begin{array}{c}\text { Dihedral } \\
\text { angle (deg) }\end{array}$ \\
\hline S1.. & 3.083 & $\mathrm{~S} 1 \mathrm{C} 1 \mathrm{C} 2 \mathrm{~S} 2$ & 13. \\
\hline$S 2 \ldots S$ & $3.119(1)$ & $\mathrm{S} 2 \mathrm{C} 2 \mathrm{C} 3 \mathrm{~S} 3$ & 13.4 \\
\hline $\mathrm{S} 1 \ldots \mathrm{S}$ & $3.401(1)$ & $\mathrm{S} 3 \mathrm{C} 3 \mathrm{C} 1 \mathrm{~S} 1$ & 12.3 \\
\hline
\end{tabular}

As there is an angle of $13.3^{\circ}$ between the plane $\mathrm{S} 1 \mathrm{CrS} 2$ and a best plane S1C1C2S2 the chelate ring is envelope shaped. Although it would be tempting to attribute this angle to the space requirements of the methyl groups at $\mathrm{C} 7$ and $\mathrm{C} 8$, this is apparently not justified, since the chelate ring in $\operatorname{Cr}(\mathrm{CO})_{4} \mathrm{~L}, \mathrm{~L}$ $=$ bis( $t$-butylthio)ethene, with far more bulky groups in the same positions is reported to be planar. ${ }^{2}$ The structure with $\mathrm{L}=$ tetrakis(methylthio)ethene (9), however, exhibits an angle of $7.03^{\circ}$ between corresponding planes in the ring.

The coordination around chromium in the present structure is octahedral with relatively little distortion. The $\mathrm{S}-\mathrm{Cr}-\mathrm{S}$ angle of $84.5^{\circ}$ is in good agreement with that reported in $\mathrm{Cr}(\mathrm{CO})_{4} \mathrm{~L}$, when $\mathrm{L}$ $=$ tetrakis(methylthio)ethene $\left(83.8^{\circ}\right)(9)$ or $\mathrm{L}=$ 3,6-dithiaoctane $\left(85.1^{\circ}\right)(5)$.

Influence of the substituents at the sulfur atom on the environment of the metal may be detected from the $\mathrm{S}-\mathrm{Cr}-\mathrm{C}$ angles, which are greater when $\mathrm{C}=$ C14 and smaller when $\mathrm{C}=\mathrm{C} 15$ (see Table 3 ). A corresponding observation has been made in similar compounds (9). ${ }^{2}$ The carbonyl group closest to sulfur is bent to an angle $\mathrm{O} 3-\mathrm{C} 15-\mathrm{Cr}$ of $173.3(6)^{\circ}$ and thus distorted most from $180^{\circ}$ with respect to the other three. It was suggested that repulsion from lone pairs of the sulfur atom might be responsible for such a distortion (5). The angle $\mathrm{C} 14-\mathrm{Cr}-\mathrm{C} 15\left(176.6^{\circ}\right)$ is significantly larger than that in some other $\mathrm{Cr}(\mathrm{CO})_{4} \mathrm{~L}$ complexes, when $\mathrm{L}=$ bis( $t$-butylthio)ethane $\left(169.8^{\circ}\right)(6), \quad \mathrm{L}=3,6$-dithiaoctane $\left(174.7^{\circ}\right)(5)$, or $\mathrm{L}=\operatorname{bis}(t$-butylthio)ethene $\left(173.5^{\circ}\right) .^{2}$

Much discussion has been presented about $\mathrm{Cr}-\mathrm{S}$ and $\mathrm{Cr}-\mathrm{C}(\mathrm{O})$ distances in similar compounds. Values found in the present structure fit

${ }^{2}$ G. M. Reisner, I. Bernal, and G. R. Dobson. To be published.
$T_{A B L E} 4$. Some bond lengths and angles in $\mathrm{Cr}(\mathrm{CO})_{4}$ $\mathrm{C}_{6}\left(\mathrm{SCH}_{3}\right)_{6}$

\begin{tabular}{lccc}
\hline Bond & Length $(\AA)$ & q Bonds & Angle(deg) \\
\hline C1-S1 & $1.794(5)$ & C6-C1-S1 & $119.1(4)$ \\
C2-S2 & $1.788(5)$ & C2-C1-S1 & $119.5(4)$ \\
S1-C7 & $1.826(6)$ & C1-C2-S2 & $120.8(4)$ \\
S2-C8 & $1.827(7)$ & C3-C2-S2 & $119.7(4)$ \\
S1-Cr & $2.368(2)$ & C1-S1-Cr & $106.7(2)$ \\
S2-Cr & $2.388(2)$ & C2-S2-Cr & $106.2(2)$ \\
Cr-C13 & $1.834(6)$ & S1-Cr-S2 & $84.55(6)$ \\
Cr-C14 & $1.893(7)$ & C1-S1-C7 & $99.9(3)$ \\
Cr-C15 & $1.863(6)$ & C2-S2-C8 & $101.7(3)$ \\
Cr-C16 & $1.849(7)$ & C14-Cr-S1 & $93.6(2)$ \\
C1-C2 & $1.396(7)$ & C14-Cr-S2 & $94.1(2)$ \\
C1-C6 & $1.384(7)$ & C14-Cr-C13 & $91.6(3)$ \\
C2-C3 & $1.404(6)$ & C14-Cr-C16 & $89.6(3)$ \\
C3-C4 & $1.416(8)$ & C15-Cr-S1 & $88.6(2)$ \\
C4-C5 & $1.403(8)$ & C15-Cr-S2 & $88.6(2)$ \\
C5-C6 & $1.409(6)$ & C15-Cr-C13 & $85.8(3)$ \\
C3-S3 & $1.771(6)$ & C15-Cr-C16 & $88.2(3)$ \\
C4-S4 & $1.770(6)$ & C14-Cr-C15 & $176.6(3)$ \\
C5-S5 & $1.765(5)$ & C13-Cr-C16 & $90.3(3)$ \\
C6-S6 & $1.775(5)$ & O1-C13-Cr & $176.3(6)$ \\
S3-C9 & $1.832(9)$ & O2-C14-Cr & $178.8(7)$ \\
S4-C10 & $1.825(8)$ & O3-C15-Cr & $173.3(6)$ \\
S5-C11 & $1.817(8)$ & O4-C16-Cr & $177.5(6)$ \\
S6-C12 & $1.801(7)$ & & \\
C13-O1 & $1.151(7)$ & & \\
C14-O2 & $1.140(10)$ & & \\
C15-O3 & $1.134(9)$ & & \\
C16-O4 & $1.163(9)$ & & \\
\hline \hline Non-bonding & & & \\
atoms & Distance $(\AA)$ & Atoms & angle (deg) \\
\hline S1..S2 & $3.199(2)$ & S1C1C2S2 & -5.4 \\
S2..S3 & $3.203(3)$ & S2C2C3S3 & +2.4 \\
S3...S4 & $3.103(3)$ & S3C3C4S4 & +13.8 \\
S4...S5 & $3.419(3)$ & S4C4C5S5 & -19.8 \\
S5...S6 & $3.089(3)$ & S5C5C6S6 & +10.3 \\
S6..S1 & $3.170(2)$ & S6C6C1S1 & +1.5 \\
\hline & & & \\
\hline & & & \\
\hline
\end{tabular}

quite well with those already reported. A shortening of the average $\mathrm{Cr}-\mathrm{S}$ bond $(2.39 \AA)(2.38 \AA$ when $\mathrm{L}=$ tetrakis(methylthio)ethene, $2.42 \AA$ when $\mathrm{L}=2,6$-dithiaoctane, and $2.44 \AA$ when $\mathrm{L}=$ 2,2,7,7-tetramethyl-3,6-dithiaoctane) compared to the sum of the assumed covalent radii $(1.48 \AA$ for $\mathrm{Cr}^{0}$ (23) and $1.04 \AA$ for sulfur (21)) has been attributed to multiple bonding between $\mathrm{Cr}$ and $\mathrm{S}$ $(5,9)$. Differences in the bond lengths $\mathrm{Cr}-\mathrm{C}(\mathrm{O})$ of carbonyl groups mutually trans and those trans to sulfur have been taken as an indicator for the lack of $\pi$-interaction in the $\mathrm{Cr}-\mathrm{S}$ bond compared to the $\mathrm{Cr}-\mathrm{C}(\mathrm{O})$ bond (5). Similar differences are observed in the present complex, $\mathrm{Cr}-\mathrm{C}(\mathrm{O})$ mutually trans being slightly longer $(1.878 \AA$ ave) than $\mathrm{Cr}-\mathrm{C}(\mathrm{O})$ trans to sulfur $(1.842 \AA$ ave $)$. Corresponding, though less significant, variations of the $\mathrm{C}-\mathrm{O}$ bond lengths are found as expected. 
TABle 5. Some data of the crystals, the data set, and the refinement

\begin{tabular}{|c|c|c|}
\hline \multirow[b]{2}{*}{ Parameter } & \multicolumn{2}{|c|}{ Value* } \\
\hline & $\mathrm{C}_{6}\left(\mathrm{SCH}_{3}\right)_{6}$ & $(\mathrm{CO})_{4} \mathrm{Cr} \cdot \mathrm{C}_{6}\left(\mathrm{SCH}_{3}\right)_{6}$ \\
\hline Crystal dimensions (mm) & $0.3 \times 0.2 \times 0.15$ & Sphere with $r=0.17$ \\
\hline Space group, molecules/unit cell & $P 2_{\mathrm{j}} / n, Z=2$ & $P 2, / n, Z=4$ \\
\hline स & $9.513(1)$ & $10.542(1)$ \\
\hline$b(\AA)$ & $6.218(1)$ & $10.764(1)$ \\
\hline$c(\AA)$ & $14.404(1)$ & $20.526(1)$ \\
\hline$\beta$ (deg) & $106.95(1)$ & $101.58(1)$ \\
\hline$V\left(\AA^{3}\right)$ & 815.0 & 2281.8 \\
\hline$\rho_{\mathrm{exp}}\left(\mathrm{Mg} \mathrm{m}^{-3}\right)$ & 1.40 & 1.49 \\
\hline$\rho_{\text {ealed }}\left(\mathrm{Mg} \mathrm{m}^{-3}\right)$ & 1.45 & 1.51 \\
\hline $2 \theta$ range & $5^{\circ}-46^{\circ}$ & $5^{\circ}-43^{\circ}$ \\
\hline \multicolumn{3}{|l|}{ Number of reflections } \\
\hline Symmetrically independent & 1119 & 2447 \\
\hline Observed & 1027 & 2260 \\
\hline Number of variables refined & 109 & 194 \\
\hline$R_{1}$ (obs. refl. only) & 0.028 & 0.048 \\
\hline (incl. unobs. refl.) & 0.031 & 0.050 \\
\hline$R_{2}$ (obs. refl. only) & 0.035 & 0.068 \\
\hline
\end{tabular}

\section{Experimental}

All reactions are studied in dry solvents, under $\mathrm{N}_{2}$. The ligands were prepared by literature methods $(14,24)$. The carbonyl complexes were available commercially or were prepared by slightly modified known procedures, $\mathrm{C}_{7} \mathrm{H}_{8} \mathrm{M}(\mathrm{CO})_{4}$ $(\mathrm{M}=\mathrm{Cr}, \mathrm{Mo}), \mathrm{Et}_{4} \mathrm{~N}\left[\mathrm{Cr}(\mathrm{CO})_{5} \mathrm{Cl}\right]$ from $\mathrm{Et}_{4} \mathrm{NCl}$ and $\mathrm{Cr}(\mathrm{CO})_{6}$, and $(\mathrm{MeCN})_{2} \mathrm{~W}(\mathrm{CO})_{4}$ from $\mathrm{MeCN}$ and $\mathrm{W}(\mathrm{CO})_{6} .{ }^{3}$

Infrared spectra were recorded in solution on a Perkin Elmer Infrared Spectrophotometer Model 283 and $\mathrm{nmr}$ spectra were recorded on a Varian T-60 (H-1) or XL-90 (F-19). Thermal analyses were studied on a DuPont Thermal Analyser 990.

Details of the reaction conditions, yields, analyses of products, and ir and nmr spectra are shown in Tables 1 and 2, respectively. Microanalyses were performed either by the Mikroanalytical Laboratory, University of Würzburg, or Mikroanalytisches Laboratorium Beller, Göttingen, W. Germany.

Structure investigation by $X$-ray methods

The crystals examined were grown from methanol $\left(\mathrm{L}_{1}\right)$ and toluene/hexane (1:2 volume ratio) $\left(\mathrm{Cr}(\mathrm{CO})_{4} \mathrm{Ll}\right)$, respectively. Some of the crystal data are given in Table 5. The lattice constants and estimated standard deviations are derived from least-squares calculations based on 19 (20) centered reflections in a $2 \theta$ range of $23^{\circ}-28^{\circ}\left(23^{\circ}-26^{\circ}\right)$ in the case of the free ligand L1 (the complex $\mathrm{Cr}(\mathrm{CO})_{4} \mathrm{~L} 1$ ). Systematic extinction was observed for reflections $h 0 l$ with $h+l=2 n+1$ and $0 k 0$ with $k=2 n+1$ leading to the space group $P 2_{1} / n$ (non standard setting of $P 2_{1} / c$, No. 19 of the International Tables) with the equivalent positions $x, y, z ;-x,-y,-z ; x+1 / 2,1 / 2-y, z+1 / 2 ; 1 / 2-x, y+1 / 2,1 / 2$ $-z$. X-ray intensity data were measured on a Syntex $P$ 2 -diffractometer. They were corrected for Lorentz and polarisation factors but not for absorption. The structure Ll was solved by direct methods (program MULTAN (25)), After refining positional parameters and anisotropic temperature factors ${ }^{4}$ for the non-hydrogen atoms by full-matrix least-squares

${ }^{3}$ W-D. Schenk. Private communication.

${ }^{4}$ Tables of the observed and calculated structure amplitudes and temperature factors are available, at a nominal charge, from the Depository of Unpublished Data, CISTI, National Research Council of Canada, Ottawa, Ont., Canada K1A 0S2. the following $R$-values were obtained: $R_{1}=0.047, R_{2}=0.074$ (observed reflections only). The quantity minimized was $\Sigma\left(\left|F_{\text {obs }}\right|-\left|F_{\text {calc }}\right|\right)^{2} \cdot W$ with $W=1 / \sigma^{2}$ and $\sigma$ derived from counting statistics. Those reflections with $I / \sigma(I)<3.0$ were classified as unobserved and not included in the refinement.

At this stage all of the 9 hydrogen atoms could be localized among the 12 highest peaks of a difference electron density map at reasonable positions. Including these in the structure factor calculations yielded $R_{1}=0.038$. Further refinement, with hydrogens kept tied to a common isotropic temperature factor, converged at $R_{1}=0.028$ and $R_{2}=0.035$. Positional parameters are listed in Table 6.

During the last cycle change/esd was less than 0.1 for all parameters.

Concerning the complex $(\mathrm{CO})_{4} \mathrm{CrLl}$ the position of the $\mathrm{Cr}$

TABle 6. Positional parameters for the crystal structure of the free ligand $\mathrm{L}_{1} \mathrm{C}_{6}\left(\mathrm{SCH}_{3}\right)_{6}$ *

\begin{tabular}{cccc}
\hline \hline Atom & $x$ & & $y$ \\
\cline { 1 - 3 } S1 & $-0.20869(8)$ & $0.35051(13)$ & $0.12475(5)$ \\
S2 & $0.14793(7)$ & $0.19090(11)$ & $0.17760(4)$ \\
S3 & $0.34537(6)$ & $0.44239(10)$ & $0.07583(4)$ \\
C1 & $-0.0884(2)$ & $0.4202(3)$ & $0.0554(2)$ \\
C2 & $0.0621(2)$ & $0.3730(3)$ & $0.0828(2)$ \\
C3 & $0.1508(2)$ & $0.4643(4)$ & $0.0305(2)$ \\
C4 & $-0.1073(5)$ & $0.4247(7)$ & $0.2471(2)$ \\
C5 & $0.0315(4)$ & $-0.0415(5)$ & $0.1477(2)$ \\
C6 & $0.3794(4)$ & $0.1984(6)$ & $0.0195(3)$ \\
H41 & $-0.186(4)$ & $0.433(6)$ & $0.277(3)$ \\
H42 & $-0.060(4)$ & $0.310(6)$ & $0.277(2)$ \\
H43 & $-0.066(4)$ & $0.562(7)$ & $0.247(3)$ \\
H51 & $0.098(4)$ & $-0.156(6)$ & $0.188(2)$ \\
H52 & $-0.021(4)$ & $-0.063(5)$ & $0.077(3)$ \\
H53 & $-0.051(4)$ & $-0.016(7)$ & $0.162(3)$ \\
H61 & $0.336(4)$ & $0.208(6)$ & $-0.049(2)$ \\
H62 & $0.490(4)$ & $0.177(6)$ & $0.037(2)$ \\
H63 & $0.336(4)$ & $0.079(5)$ & $0.048(3)$ \\
\hline
\end{tabular}

* Estimated standard deviations are given in parentheses and correspond to the least significant digits. 
atom in the unit cell could be found from a Patterson synthesis. Successive structure factor, Fourier and difference Fourier calculations revealed the positions of the lighter atoms except hydrogen. All atoms except $\mathrm{Cl}, \ldots, \mathrm{C} 6$ and $\mathrm{C} 13, \ldots, \mathrm{C} 16$ were made anisotropic. Positional parameters as resulting from full-matrix least-squares refinement are given in Table 7. The maximum change/esd during the last cycle was 0.01 and there were no values above $0.5 \mathrm{e} / \AA^{3}$ in the final difference electron density map. $R$-values are given in Table 5 .

All calculations were carried out by means of the XTLprogramme (26) package on a NOVA 1200 minicomputer with structure factors for uncharged atoms as given in ref. 27 . Effects of anomalous dispersion were not taken into account.

\section{Methods}

Reactions with $\mathrm{C}_{7} \mathrm{H}_{8} \mathrm{M}(\mathrm{CO})_{4}, \mathrm{M}=\mathrm{Cr}, \mathrm{Mo}($ Method $\mathrm{A})$

Equimolecular amounts $(1 \mathrm{mmol})$ of $\mathrm{C}_{7} \mathrm{H}_{8} \mathrm{M}(\mathrm{CO})_{4}$ and ligand were dissolved in $\sim 20 \mathrm{~mL}$ toluene and heated to approximately $45^{\circ} \mathrm{C}$. The reaction was monitored by observing changes in the ir spectrum in the $2100-1750 \mathrm{~cm}^{-1}$ region. When the reaction was approximately $90 \%$ complete, any precipitate was filtered off, and further product precipitated by addition of an equal volume of hexane. The products were recrystallized from toluene/hexane.

The nmr spectra and thermal analysis of the Mo products, $\mathrm{Mo}(\mathrm{CO})_{4} \mathrm{~L}$, showed that they contained some solvent which was lost before the product decomposed. The excess solvent was removed by carefully heating in vacuum.

Reactions with stoichiometry $2: 1 \quad \mathrm{C}_{7} \mathrm{H}_{8} \mathrm{Mo}(\mathrm{CO})_{4}: \mathrm{L}$ were studied in either toluene at $45^{\circ} \mathrm{C}$, or methylene chloride $\left(\sim 35^{\circ} \mathrm{C}\right)$ when precipitation had occurred in toluene. The reaction was monitored by ir or nmr spectra. In the reactions with $\mathrm{L} 2, \mathrm{~L} 5$, and

TABle 7. Positional parameters $\left(\times 10^{4}\right.$, for $\mathrm{Cr} \times$ $\left.10^{5}\right)$ for non-hydrogen atoms in the crystal structure of the complex $\mathrm{Cr}(\mathrm{CO})_{4} \mathrm{Ll}$ with esd's in parentheses

\begin{tabular}{ccrr}
\hline \hline Atom & \multicolumn{1}{c}{$x$} & \multicolumn{1}{c}{$y$} \\
\hline Cr & $25965(9)$ & $22032(8)$ & $718(4)$ \\
S1 & $4233(1)$ & $3179(1)$ & $-385(1)$ \\
S2 & $2116(1)$ & $1121(1)$ & $-964(1)$ \\
S3 & $2376(2)$ & $-365(2)$ & $-2283(1)$ \\
S4 & $4493(2)$ & $389(2)$ & $-3062(1)$ \\
S5 & $7212(1)$ & $1671(2)$ & $-2110(1)$ \\
S6 & $6773(2)$ & $3416(1)$ & $-981(1)$ \\
C1 & $4382(5)$ & $2304(4)$ & $-1110(2)$ \\
C2 & $3420(5)$ & $1450(4)$ & $-1376(2)$ \\
C3 & $3536(5)$ & $773(5)$ & $-1946(2)$ \\
C4 & $4599(5)$ & $1008(5)$ & $-2254(3)$ \\
C5 & $5657(5)$ & $1697(5)$ & $-1914(2)$ \\
C6 & $5505(5)$ & $2407(4)$ & $-1358(2)$ \\
C7 & $3744(6)$ & $4681(5)$ & $-768(3)$ \\
C8 & $745(6)$ & $1826(8)$ & $-1529(3)$ \\
C9 & $3129(10)$ & $-1751(7)$ & $-1852(5)$ \\
C10 & $5145(8)$ & $1633(8)$ & $-3502(3)$ \\
C11 & $7468(7)$ & $45(7)$ & $-2284(4)$ \\
C12 & $7635(7)$ & $2418(7)$ & $-337(3)$ \\
C13 & $3152(6)$ & $2960(6)$ & $879(3)$ \\
C14 & $1373(7)$ & $3478(7)$ & $-210(3)$ \\
C15 & $3776(6)$ & $954(6)$ & $399(3)$ \\
C16 & $1362(7)$ & $1335(6)$ & $412(3)$ \\
O1 & $3547(5)$ & $3382(4)$ & $1395(2)$ \\
O2 & $651(6)$ & $4261(6)$ & $-373(3)$ \\
O3 & $4493(6)$ & $239(5)$ & $658(3)$ \\
O4 & $614(5)$ & $794(5)$ & $649(2)$ \\
\hline & & &
\end{tabular}

L6 in $\mathrm{CH}_{2} \mathrm{Cl}_{2}$, the infrared spectrum showed that approximately $50 \%$ of the $\mathrm{C}_{7} \mathrm{H}_{8} \mathrm{Mo}(\mathrm{CO})_{4}$ had reacted within $20 \mathrm{~h}$, and that any subsequent reaction was very slow, probably a decomposition generating increasing amounts of $\mathrm{Mo}(\mathrm{CO})_{6}$. After 4 or 5 days, the $\mathrm{nmr}$ spectrum showed that the main product formed was $\mathrm{Mo}(\mathrm{CO})_{4} \mathrm{~L}$ and only traces of possible $\left[\mathrm{Mo}(\mathrm{CO})_{4}\right]_{2} \mathrm{~L}$ could be detected.

Reactions with $M(C O)_{6}, M=C r, W($ Method $B)$

The experimental details have been described previously (1).

Reactions with $\mathrm{W}(\mathrm{CO})_{4}(\mathrm{MeCN})_{2}($ Method $\mathrm{C})$

A solution of approximately $1.7 \mathrm{mmol} \mathrm{W}(\mathrm{CO})_{4}(\mathrm{MeCN})_{2}$ in $20 \mathrm{~mL}$ THF was filtered into a solution of the ligand $(1.0 \mathrm{mmol})$ in $10 \mathrm{~mL}$ THF. The infrared spectrum showed that the reaction was complete at room temperature within less than $2 \mathrm{~h}$, i.e. specifically the band at $1853 \mathrm{~cm}^{-1}$ attributed to $\mathrm{W}(\mathrm{CO})_{4}(\mathrm{MeCN})_{2}$ (28) had disappeared. Any $\mathrm{W}(\mathrm{CO})_{s} \mathrm{MeCN}$ did not react, as no change was observed in the band at $1840 \mathrm{~cm}^{-1}(28)$. The solvent was removed and the product extracted with $20 \sim 30 \mathrm{~mL}$ toluene. The product was precipitated on addition of an equal volume of hexane. It was recrystallized from a mixture of hexane and toluene.

In the reactions with approximately $3 \mathrm{mmol} \mathrm{W}(\mathrm{CO})_{4}(\mathrm{MeCN})_{2}$ and $1 \mathrm{mmol}$ ligand, the residue after the toluene extraction to remove $\mathrm{W}(\mathrm{CO})_{4} \mathrm{~L}$ was further extracted with $\mathrm{CH}_{2} \mathrm{Cl}_{2}$. The product $\left[\mathrm{W}(\mathrm{CO})_{4}\right]_{2} \mathrm{~L}$ was precipitated on slow addition of toluene. In reactions with $\mathrm{L} 3$ and $\mathrm{L} 5, \mathrm{~W}(\mathrm{CO})_{4} \mathrm{~L}$ was the only complex detected in the $\mathrm{nmr}$ spectra of the products.

Reactions with $\left.\mathrm{Et}_{4} \mathrm{~N} / \mathrm{Cr}(\mathrm{CO})_{5} \mathrm{Cl}\right]($ Method D)

Approximately $1 \mathrm{mmol}$ of $\mathrm{Et}_{4} \mathrm{~N}\left[\mathrm{Cr}(\mathrm{CO})_{5} \mathrm{Cl}\right]$ was added to a solution of $0.5 \mathrm{mmol}$ of ligand in $60 \mathrm{~mL} \mathrm{EtOH}$ at room temperature. The solution was stirred. If precipitation had not occurred within 1 day, approximately $5 \mathrm{~mL}$ of $\mathrm{H}_{2} \mathrm{O}$ was added. The volume of the solution was reduced until a precipitate had formed. The precipitate was extracted with toluene to remove $\mathrm{Cr}(\mathrm{CO})_{4} \mathrm{~L}$ and the residue with $\mathrm{CH}_{2} \mathrm{Cl}_{2}$. The product $\left[\mathrm{Cr}(\mathrm{CO})_{4}\right]_{2} \mathrm{~L}$ reprecipitated on addition of toluene.

\section{Acknowledgements}

One of the authors (M. E. P.) wishes to thank Prof. Dr. Max Schmidt for the hospitality in Würzburg and the Alexander von Humboldt Stiftung (Bonn) for a fellowship while on leave from Acadia University. Dr. W-D. Schenk is thanked for many helpful discussions.

1. W. J. Frazee and M. E. Peach. Phosphorus Sulfur, 6, 407 (1978).

2. J. A. Connor and G. A. Hudson. J. Chem. Soc. Dalton Trans. 1025 (1975).

3. E. W. Ainscough, E. J. BirCh, and A. M. Brodie. Inorg. Chim. Acta, 20, 187 (1976).

4. G. R. Dobson. Inorg. Chem. 8, 80 (1969).

5. E. N. Baker and N. G. Larsen. J. Chem. Soc. Dalton Trans. 1769 (1976).

6. G. M. Reisner, I. Bernal, and G. R. Dobson. Inorg. Chim. Acta, 50, 227 (1981).

7. R. Ros, M. Vidali, and R. Graziani. Gazz. Chem. Ital. 100, 407 (1970).

8. E. W. Ainscough, A. M. Brodie, N. G. Larsen, and R. G. MatThEWs. Inorg. Chim. Acta, 49, 159 (1981).

9. M. F. Lappert, D. B. Shaw, and G. M. Mclaughlin. J. Chem. Soc. Dalton Trans. 427 (1979).

10. B. K. Balbach, A. R. Koray, A. OKur, P. Wuelknitz, and M. L. Ziegler. J. Organomet. Chem. 212, 77 (1981). 
11. A. R. Koray and M. L. Ziegler. J. Organomet. Chem. 202, 13 (1980).

12. D. SEvič and H. Meider. J. Inorg. Nucl. Chem. 43, 153 (1981).

13. A. R. Sanger, C. G. Lobe, and J. E. Weiner-Fedorak. Inorg. Chim. Acta, 53, L123 (1981).

14. M. E. PEACH and E. S. RAYNER. J. Fluorine Chem. 13, 447 (1979).

15. A. Trenkle and H. Vahrenkamp. Chem. Ber. 114, 1343 (1981).

16. D. J. Darensbourg and R. L. Kump. Inorg. Chem. 17, 2680 (1978).

17. M. E. PEACH and A. M. Smith. J. Fluorine Chem. 4, 341 (1974).

18. H. BURDORF and C. EISCHENBROICH. Z. Naturforsch. 36b, 94 (1981).

19. M. Herberhold and G. Suss. J. Chem. Res.(S), 246 (1977).

20. H. G. Raubenheimer, J. C. A. Boyens, and S. Lotz. J. Organomet. Chem. 112, 145 (1976).
21. L. Pauling. Nature of the chemical bond. 3rd ed. Cornell University Press, Ithaca, New York. 1960. p. 225.

22. W. R. Blackmore and S. C. Abrahams. Acta Crystallogr. 8, 329 (1955).

23. F. A. Cotton and D. C. Richardson. Inorg. Chem. 5, 1851 (1966).

24. K. R. Langille and M. E. Peach. J. Fluorine Chem. 1, $407(1971 / 2)$

25. G. Germain, P. Main, and M. M. Woolfson. Acta Crystallogr. 27A, 368 (1971)

26. Syntex-XTL-Systems (1976), Syntex Analytical Instruments, Cupertino, CA.

27. D. T. Cromer and J. T. WABER. International tables for X-ray crystallography. Vol. IV. Kynoch Press, Birmingham. 1974. pp. 99-101.

28. G. R. Dobson, M. F. Amir El Sayer, I. W. Stolz, and R. K. Sheline. Inorg. Chem. 1, 526 (1962). 